\title{
Role of population traits and local social interactions in sex-change plasticity of the protandric marine gastropod Crepidula coquimbensis
}

\author{
Antonio Brante* ${ }^{*}$ Carlos Vilches, Adriana Quiñones \\ Departamento de Ecología, Facultad de Ciencias, Universidad Católica de la Santísima Concepción, Casilla 297, \\ Concepción, Chile
}

\begin{abstract}
Theoretical and experimental work suggests that time to sex change in sequential hermaphrodites may be strongly linked to local population traits and the social environment of the individuals. We evaluated social control and temporal and spatial plasticity in the sex-change response of the protandric marine gastropod Crepidula coquimbensis, which inhabits the empty shells of other gastropods and reproduces via direct development. Over 2 yr, 2 populations with significant genetic distance were sampled, and the abundance, population sex ratio, and sex ratio within hosting shells was measured. Reproductive responses, minimum female size, and the size at which $50 \%$ of the males changed sex to female $\left(\mathrm{L}_{50}\right)$ were calculated for each location and sampling date. The sex ratio was male-biased in all cases. High temporal and spatial variability in the abundance, sex ratio, and body size at sex change was observed. However, negative and significant correlations were found between minimum female size and number of males in the aggregation and between population sex ratio and $\mathrm{L}_{50}$. Although earlier studies have suggested that sexchange strategy of gastropod species with direct development is less plastic and responsive to conspecifics, the present work indicates that the protandric marine gastropod C. coquimbensis may adjust its sexual strategy to local social conditions.
\end{abstract}

KEY WORDS: Sequential hermaphroditism $\cdot$ Life-history strategy $\cdot$ Size advantage $\cdot$ Population genetics $\cdot$ Sex ratio

Resale or republication not permitted without written consent of the publisher

\section{INTRODUCTION}

Sex-change strategy is observed across taxa, and recent evidence suggests that time to sex change is a plastic trait (Munday et al. 2006). According to experimental and field data, the timing of sex change may be strongly linked to local population traits (i.e. density, sex rate) and the social environment of the individuals (i.e. social groups or aggregations), responding in a way that maximizes reproductive output (Munday et al. 2006). Thus, local conditions will modulate individual responses and overall sex-change strategies.

According to the size-advantage theory, optimal size for sex change will occur when the potential sub- sequent lifetime reproductive value as the second sex exceeds that of remaining as the first sex (Charnov 1979, 1982). Empirical studies to understand the evolution and diversity of sequential hermaphroditism have been carried out in protogynous fishes (e.g. Hoffman et al. 1985, Allsop \& West 2003, Muñoz \& Warner 2003, 2004), protandric mollusks (e.g. Hoagland 1978, Collin 1995, 2006, Warner et al. 1996, Collin et al. 2005, Dupont et al. 2006), and to a lesser extent in crustaceans and polychaete worms, which combine simultaneous and sequential hermaphroditic strategies during their lifetime (e.g. crustaceans: Charnov 1978, 1979, Bauer 1986, Juchault 1999, Baeza 2006, 2007; polychaetes: Sella 1990, Lorenzi et al. 2005). In sequential hermaphroditic 
fishes and crustaceans, evidence suggests that strategies modulating sex change are complex and indicate a degree of fine-tuning by population traits (e.g. fishes: Ross et al. 1983, Alonzo \& Warner 2000, Petersen et al. 2001, Muñoz \& Warner 2004; crustaceans: Baeza 2006). Thus, temporal and spatial intraspecific plasticity observed at the time of sex change in these groups may be explained by demographic parameters such as density, body size (or age) structure, and sex ratio (e.g. Ross et al. 1983, Alonzo \& Warner 2000, Petersen et al. 2001, Baeza 2006).

In protandric marine gastropods, field and experimental studies carried out on species from different taxa (Calyptraeidae, Coralliophilidae, and limpets) suggest social regulation of sex change (Wright 1989, Soong \& Chen 1991, Chen et al. 1998, 2004, Collin 2000, Chen \& Soong 2003, Richter \& Luque 2004, Rivera-Ingraham et al. 2011). For example, in Patella ferruginea, lower frequencies of large individuals correlate with smaller sizes at sex change (RiveraIngraham et al. 2011). Aggregate composition, sex ratio, and presence or absence of females influences size and timing at sex change in ectobiotic coralliophilids (Chen et al. 1998, 2004, Richter \& Luque 2004, Soong \& Chen 1991) and in species of the genus Crepidula (Collin 1995, 2000, 2006, Collin et al. 2005). Thus, sex-change strategy appears to be highly plastic, and social conditions would be expected to promote different sex-change responses in marine protandric gastropod species.

However, social influence on sex-change strategy will depend on the spatial scale at which individuals interact. It has been proposed that marine protandric gastropods with low dispersal potential, such as direct developers, will be less responsive to conspecifics and will show low sex-change plasticity (Coe 1938, Hoagland 1978). Nevertheless, according to Collin et al. (2005), there is no theoretical expectation that mode of development should be associated with strategies of sex change. In fact, the few experimental works carried out on protandric gastropods with direct development have shown that these species present similar responses to conspecifics in their sex-change strategy compared to species with planktonic development (Warner et al. 1996, Collin et al. 2005).

Crepidula coquimbensis is a calyptraeid with direct development that cohabits with hermit crabs inside empty shells of other marine gastropods. Social interaction is restricted to individuals sharing the same hosting shell. Groups are formed by 2 to 5 individuals, with usually 1 sedentary female and 1 to
4 mobile males. Laboratory observations suggest low mobility of males, and molecular data show high fidelity of individuals to the aggregation (Brante et al. 2011). In the present study, we used C. coquimbensis as a model to test the effect of social structure on temporal and spatial plasticity patterns of sex change in a species with direct development and moderate social interaction, and we hypothesized that: (1) $C$. coquimbensis is highly responsive to conspecifics, showing high temporal and spatial variability of size at sex change, and (2) local aggregation structure (sex ratio and number of males) at the hosting shell level will modulate sex change time independent of the source population. Dispersal potential and population status of each location was evaluated through population genetic analyses using the cytochrome $C$ oxidase subunit I (COI) gene.

\section{MATERIALS AND METHODS}

\section{Biological model}

Crepidula coquimbensis is a protandric species of the family Calyptraeidae. As with all members of the calyptraeid group, fertilization in this species is internal, and males transfer sperm during mating. Females encapsulate and brood their offspring for a period of $\sim 40 \mathrm{~d}$. Reproductive females are observed all year round. C. coquimbensis is a direct developer, with juveniles hatching from capsules at the end of the incubation time. This species exhibits gregarious behavior, with 1 female and between 1 and 4 males cohabiting the same gastropod hosting shell (e.g. genera Tegula and Argobuccinum) that a hermit crab uses (Brown \& Olivares 1996). Females are sedentary, while juveniles and males show moderate mobility (A. Brante pers. obs.). Preliminary laboratory experiments have shown that the hermit crab is the only vector for juveniles and males to move among hosting shells and colonize new microhabitat. These life-history characteristics and preliminary laboratory observations would suggest low levels of dispersal potential in C. coquimbensis. Restricted migration rates and highly structured populations would thus be expected.

\section{Fieldwork}

Sampling was carried out at 3 locations in centralnorthern Chile, distributed along $\sim 40 \mathrm{~km}$ of coast: La Herradura I ( $\left.29^{\circ} 57^{\prime} 59^{\prime \prime} \mathrm{S}, 71^{\circ} 21^{\prime} 11^{\prime \prime} \mathrm{W}\right)$, La Herra- 


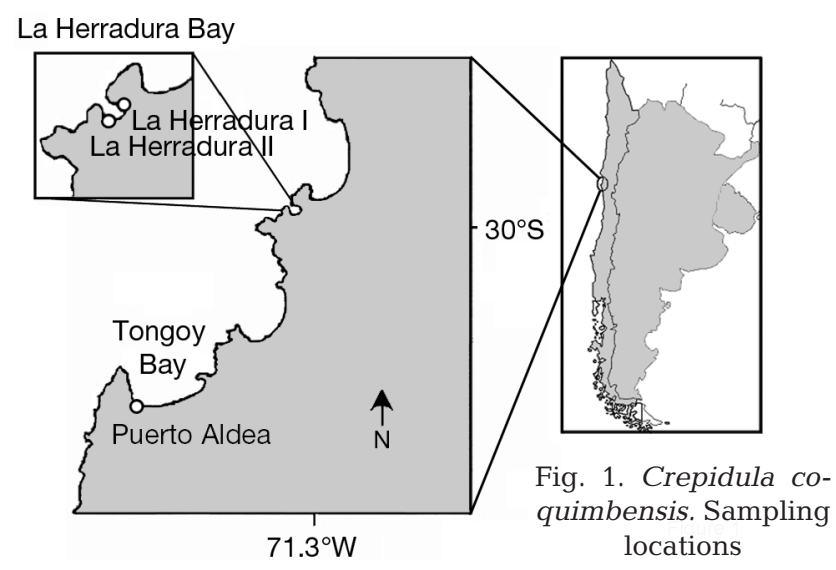

dura II $\left(29^{\circ} 58^{\prime} 59^{\prime \prime} \mathrm{S}, 71^{\circ} 21^{\prime} 41^{\prime \prime} \mathrm{W}\right)$, and Puerto Aldea (30॰11' 30" S, 71² 25' 24" W; Fig. 1). La Herradura I and II are located inside La Herradura Bay, while Puerto Aldea is located to the south, inside Tongoy Bay (Fig. 1). Sampling was conducted on 4 occasions: twice a year, during winter and summer, in 2010 and 2011. A total of 50 quadrats of $50 \times 50 \mathrm{~cm}$ were haphazardly sampled at each location and time by SCUBA divers. All shells inhabited by Crepidula coquimbensis in each quadrat were collected and stored in plastic bags for later analyses. Samples were transported in coolers filled with seawater to the Faculty of Science of the Universidad Católica de la Santísima Concepción, Concepción, Chile.

\section{Population genetics}

In order to estimate population genetic differences between the sampled locations, between 26 and 29 individuals from each location were used for genetic analyses (see Table 1). DNA was extracted using the standard salt protocol. We used the universal primers designed by Folmer et al. (1994) to amplify the mitochondrial COI gene. PCR amplifications were performed in $10 \mu \mathrm{l}$ of reaction volume containing $0.2 \mathrm{U}$ $\mathrm{ul}^{-1}$ of Taq DNA polymerase (Invitrogen), $1 \times$ reaction buffer, $0.25 \mathrm{mM}$ dNTPs, $1.5 \mathrm{mM} \mathrm{MgCl}_{2}, \mathrm{BSA} 1 \times, 0.10$ $\mu \mathrm{mol}$ of each primer, and $\sim 6 \mathrm{ng} \mathrm{ul}^{-1}$ of template DNA. The PCR began with an initial denaturation (1 min at $\left.94^{\circ} \mathrm{C}\right)$ followed by 35 cycles at $95^{\circ} \mathrm{C}(30 \mathrm{~s}), 49^{\circ} \mathrm{C}(55 \mathrm{~s})$, and $72^{\circ} \mathrm{C}(1 \mathrm{~min}$ and $30 \mathrm{~s})$, and a final extension at $72^{\circ} \mathrm{C}(10 \mathrm{~min})$. PCR products were sent to Macrogen (Korea) for sequencing. Sequences were edited and aligned using BioEdit 7.0 software (Hall 1999).

Standard genetic diversity indices such as number of haplotypes $\left(\mathrm{N}_{\text {hap }}\right)$, number of segregating sites $(\mathrm{S})$, haplotype diversity $\left(\mathrm{H}_{\mathrm{e}}\right)$, and nucleotide diver- sity $(\pi)$ were estimated for each location using DnaSP software version 5 (Rozas \& Rozas 1995). The population genetic distance of Crepidula coquimbensis was studied by calculating both global and pairwise fixation index $\left(F_{\mathrm{ST}}\right)$ between locations. The significance of pairwise $F_{\mathrm{ST}}$ was based on 10000 permutations as implemented in Arlequin software (Excoffier et al. 1992). To visualize the spatial distribution of the haplotypes, we constructed a haplotype network using the median joining algorithm implemented in Network 4.5.1 software (Bandelt et al. 1999). We applied a maximum parsimony algorithm to simplify the complex branching pattern and to represent the most parsimonious intraspecific phylogenies (Polzin \& Daneshmand 2003). Finally, demographic or selective history at the mtDNA locus was examined by calculating Tajima's $D$ (Tajima 1989) in Arlequin software.

\section{Population traits}

For the analyses of population traits, only La Herradura I and Puerto Aldea were considered, given the high and significant population genetic differences observed between both locations (see 'Results'). In the laboratory, all individuals of Crepidula coquimbensis were removed from their hosting shell under a binocular microscope using forceps. Each individual was measured with calipers to the nearest $0.01 \mathrm{~cm}$ and sexed according to body size and the presence of sexual organs (Brown \& Olivares 1996, Véliz et al. 2003). Males and females were classified by the presence or absence of a penis and female genital papilla. Juveniles were individuals with a shell length $<7 \mathrm{~mm}$ and lacking a penis, while transitional individuals had both a penis and female genital papilla, or were $>8 \mathrm{~mm}$ and lacking a penis or female genital papilla. Sexual size dimorphism was tested with Student's $t$-tests for each locality. A total of 1523 individuals were analyzed.

For each location and sampling period, we described the following population traits: population density, number of individuals per hosting shell, sizegender distributions, population sex ratio, and sex ratio within hosting shells. Mean population densities, mean number of individuals per hosting shell, and mean hosting shell sex ratios were compared with a 3-way ANOVA with location, year, and season as fixed factors. Prior to analysis, the data of mean population density and mean number of individuals per hosting shells were root-transformed to meet ANOVA assumptions. Differences between localities 
in male and female sizes were tested with Student's $t$-tests, separately for each sex. Spearman's rank correlations were performed for each locality in order to explore whether spatial and temporal variation in population abundance of Crepidula coquimbensis was related to variation in the number of individuals per hosting shell or number of hosting shells per $\mathrm{m}^{2}$ occupied by C. coquimbensis,

Population sex ratio was compared with respect to an unbiased proportion of males and females with chi-squared tests for each location and season. We expected colonizing populations with high recruiting rates to have high densities and high sex ratios, and older populations to present a more stable demographic structure with lower sex ratios and lower densities. We used Spearman's rank correlation test to discard the possibility that differences in population sex ratios between localities and sampling times were due to differences in population densities. Given that local social interactions between individuals of Crepidula coquimbensis are produced within hosting shells, mean sex ratio within hosting shells was calculated and compared with a hypothetical value of 1, assuming no sex-bias, using Student's $t$ tests for each location and sampling period.

In order to explore the effect of social interactions on the determination of the sex-change size, we correlated, for each population, the mean value of the smallest female size in the aggregates observed in each sample unit (quadrat) with the mean number of males per aggregate in the corresponding sample unit. We also calculated the size at which sex change occurs in the field using a logistic regression to predict the size at which $50 \%$ of the individuals were males ( $\mathrm{L}_{50}$; Allsop \& West 2003). $\mathrm{L}_{50}$ was correlated with population mean sex ratio within hosting shells. Significance of correlations (minimum female size and $\mathrm{L}_{50}$ ) was tested using Spearman's rank correlation tests.

\section{RESULTS}

\section{Population genetics}

A total of $626 \mathrm{bp}$ of the COI gene were analyzed in 83 individuals from the 3 locations sampled. We found a total of 19 haplotypes, ranging from 5 haplotypes in La Herradura II to 11 haplotypes in Puerto Aldea, with a total of 26 segregating sites (Table 1). Puerto Aldea had the highest values of both genetic diversity indexes estimated, $\mathrm{H}_{\mathrm{e}}$ and $\pi$, while La Herradura I had the lowest diversities (Table 1).
Table 1. Crepidula coquimbensis. Mitochondrial diversity in the cytochrome $c$ oxidase subunit I (COI) gene. n: sample size, bp: no. of base pairs, $\mathrm{N}_{\text {hap }}$ : number of haplotypes, $\mathrm{H}_{\mathrm{e}}$ : haplotype diversity, $\mathrm{S}$ : no. of segregating sites, $\pi$ : nucleotide diversity

\begin{tabular}{|lccrcrc|}
\hline Locality & $\mathrm{n}$ & $\mathrm{bp}$ & $\mathrm{N}_{\text {hap }}$ & $\mathrm{H}_{\mathrm{e}}$ & $\mathrm{S}$ & $\pi$ \\
\hline Puerto Aldea & 26 & 626 & 11 & 0.78 & 15 & 0.0030 \\
La Herradura I & 28 & 626 & 6 & 0.33 & 6 & 0.0008 \\
La Herradura II & 29 & 626 & 5 & 0.63 & 8 & 0.0017 \\
Overall & 83 & 626 & 19 & 0.74 & 26 & 0.0023 \\
& & & & & & \\
\hline
\end{tabular}

Table 2. Crepidula coquimbensis. Fixation index $\left(F_{\mathrm{ST}}\right)$ pairwise comparisons between the 3 locations. All values of $F_{\mathrm{ST}}$ were significant $(p<0.05)$

\begin{tabular}{|lccc|}
\hline & \multirow{2}{*}{ Puerto Aldea } & \multicolumn{2}{c|}{ La Herradura } \\
& & I & II \\
\hline Puerto Aldea & 0 & & \\
La Herradura I & 0.39 & 0 & \\
La Herradura II & 0.27 & 0.06 & 0 \\
\hline
\end{tabular}

The global $F_{\mathrm{ST}}$ value of 0.3 was significant $(\mathrm{p}<$ 0.05). All $F_{\mathrm{ST}}$ pairwise comparisons between locations were significant $(\mathrm{p}<0.05)$, with the lowest genetic differentiation observed between the sites inside La Herradura Bay (La Herradura I and II), and the highest values recorded between the different bays (Table 2). The haplotype network exhibited 2 common haplotypes, $\mathrm{H} 1$ and $\mathrm{H} 2$, separated by 1 mutational step (Fig. 2). The most frequent haplotype (H1) was exclusive to La Herradura Bay (La Herradura I and II), while $\mathrm{H} 2$ was shared by Puerto Aldea and La Herradura I samples. All haplotypes derived from those most common haplotypes were exclusive to the sampled bay (La Herradura Bay and Tongoy Bay; Fig. 2).

The overall Tajima's test for the 3 locations had a significant and negative value $(D=-2.3, \mathrm{p}<0.05)$. Similarly, significant and negative Tajima's $D$ values were observed in Puerto Aldea $(D=-1.8, \mathrm{p}<0.05)$ and La Herradura I $(D=-1.5, \mathrm{p}<0.05)$. La Herradura II had a negative but non-significant value.

\section{Population traits}

Presence of Crepidula coquimbensis was recorded in $\sim 60.5 \%$ of potential host shells sampled in Puerto Aldea and in $45.7 \%$ of potential host shells in La Herradura I. Mean population abundance of this species 


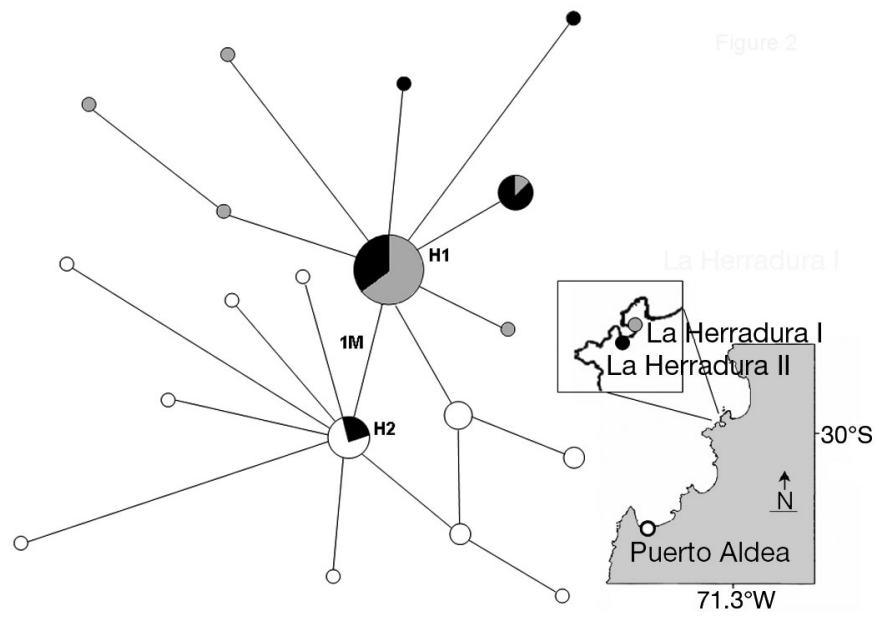

Fig. 2. Crepidula coquimbensis. Haplotype network of the mtDNA gene detected in 83 individuals from the 3 populations sampled. Haplotype circle sizes are proportional to the number of individuals. One mutational step (1M) separates the 2 most frequent haplotypes ( $\mathrm{H} 1$ and $\mathrm{H} 2)$
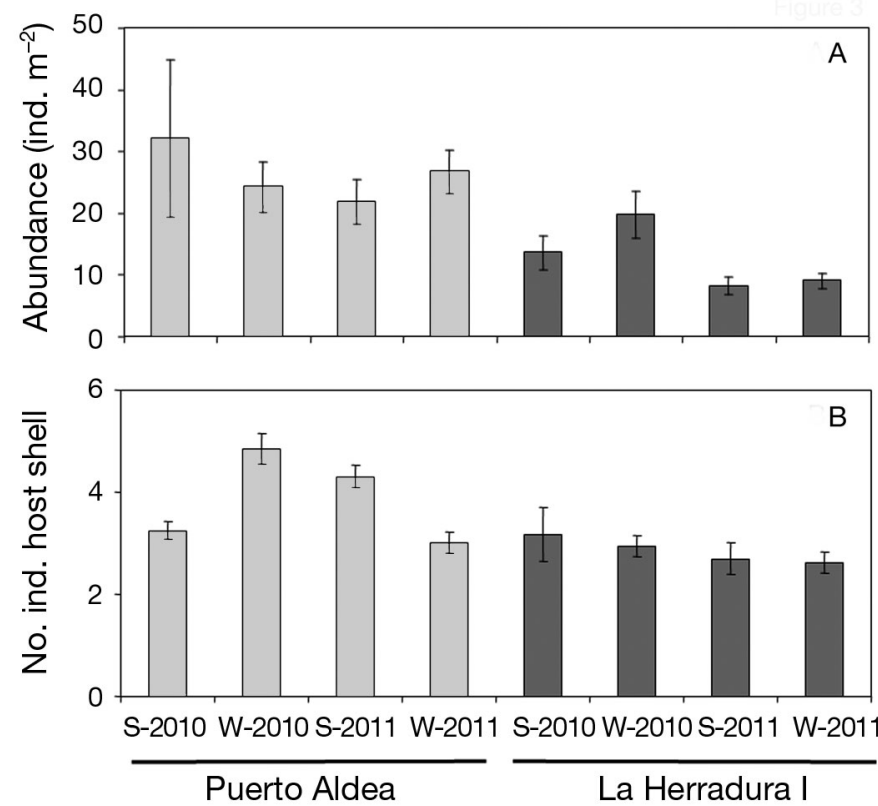

Fig. 3. Crepidula coquimbensis. (A) Abundance and (B) number of individuals per hosting shell at Puerto Aldea and La Herradura I. S: summer, W: winter. Means \pm 1 SE

was highly variable, at temporal and spatial scales, ranging between $9.04 \pm 1.3(\mathrm{SE})$ and $32.12 \pm 12.8$ ind. $\mathrm{m}^{-2}$ throughout the whole sampling period (Fig. 3A). Significant differences in abundance were only detected between locations, with Puerto Aldea exhibiting higher abundances (3-way ANOVA: $F_{1,372}$ $=19.73, \mathrm{p}<0.001$ ). Mean number of individuals of $C$. coquimbensis per hosting shell was also variable, with the highest and lowest values observed in Puerto Aldea during winter $2010(4.86 \pm 0.3 \mathrm{SE})$ and winter 2011 (3.01 $\pm 0.2 \mathrm{SE})$, respectively (Fig. 3B). The ANOVA showed a significant effect in the interaction term Year $\times$ Locality $\times$ Season (3-way ANOVA: $\left.F_{1,476}=13.51, \mathrm{p}<0.001\right)$. Puerto Aldea in winter 2010 differed significantly from the other treatments, except for Puerto Aldea in summer 2011 (Tukey's a posteriori test: $\mathrm{p}<0.05$; Fig. 3B); also, this last treatment did not differ from Puerto Aldea in summer 2010 and La Herradura I in summer 2010 (Tukey's a posteriori test: $\mathrm{p}<0.05$; Fig. 3B). Mean population abundance correlated with the number of hosting shells per $\mathrm{m}^{2}$ occupied by C. coquimbensis (Spearman's rank correlation: $\mathrm{r}_{\mathrm{S}}=0.85, \mathrm{p}<0.001$ ) but did not correlate with the mean number of individuals per hosting shell (Spearman's rank correlation: $r_{S}=$ $0.64, \mathrm{p}=0.09$ ).

Of the shells inhabited by Crepidula coquimbensis, $16.7 \%$ were occupied only by males or juveniles. The remaining hosting shells $(83.3 \%)$ contained at least 1 female. Population sex ratio was male-biased at both locations at all sampling times (chi-squared test: $\mathrm{p}<$ 0.05 in all cases; Fig. 4A). Similarly, mean sex ratio within hosting shells departed significantly from the expected value of 1 (no sex-bias) in all cases (loca-

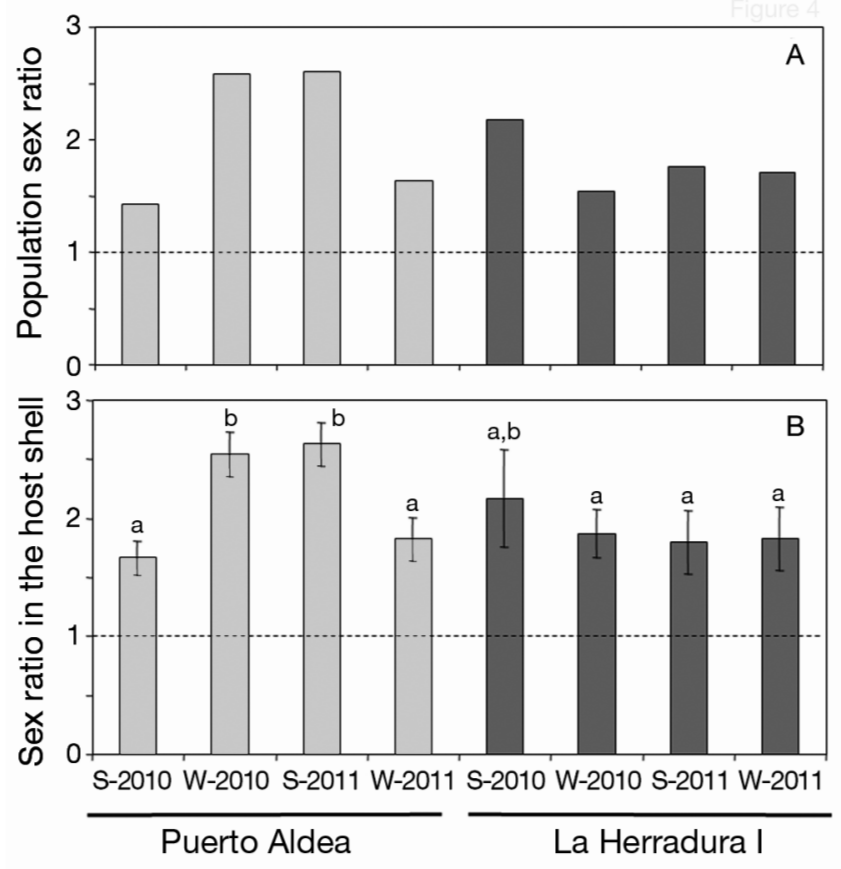

Fig. 4. Crepidula coquimbensis. (A) Population sex ratio (males:females) and (B) sex ratio within hosting shell at Puerto Aldea and La Herradura I. Lowercase letters in (B) indicate significance differences between locations and sampling dates. S: summer, W: winter. Means $\pm 1 \mathrm{SE}$ 
tions and sampling times), indicating a male-biased sex ratio (Student's $t$-test: $\mathrm{p}<0.05$ in all comparisons; Fig. 4B). The ANOVA indicated high variability in the sex ratio within hosting shells at spatial and temporal scales but without a clear pattern (3-way ANOVA with interaction term Year $\times$ Locality $\times$ Sea- son: $\left.F_{1.270}=5.49, \mathrm{p}<0.05\right)$. No significant correlation was observed between sex ratio and population density (Spearman's rank correlation: $\mathrm{r}_{\mathrm{S}}=-0.02, \mathrm{p}=$ 0.95).

Body size range for the different life-cycle stages (juvenile, male, transition, and female) varied be-

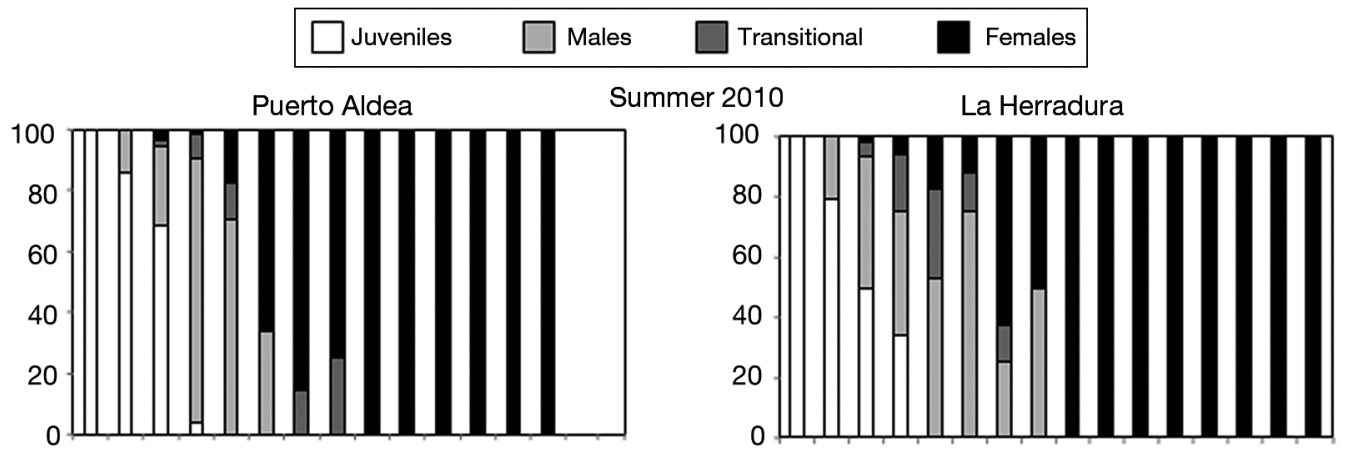

Winter 2010

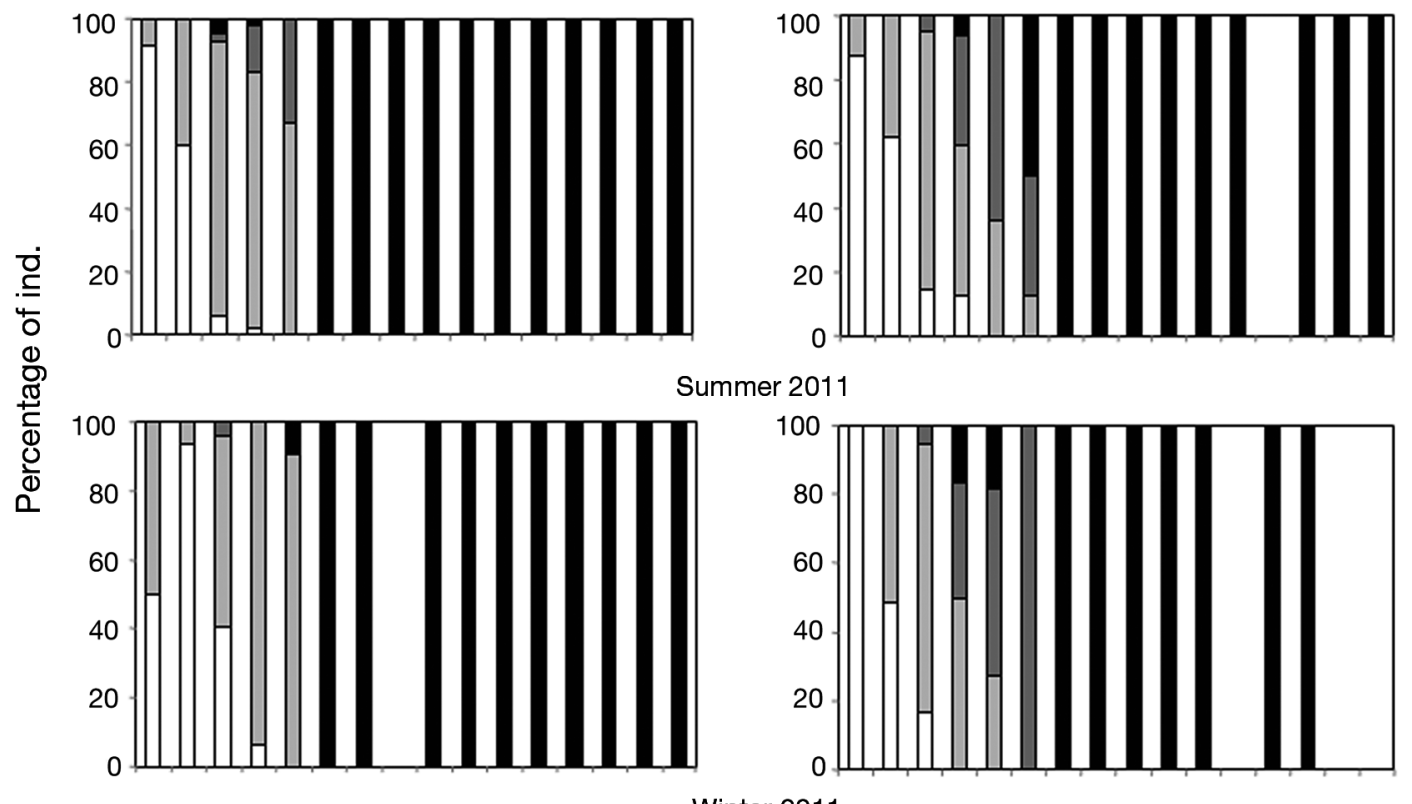

Winter 2011
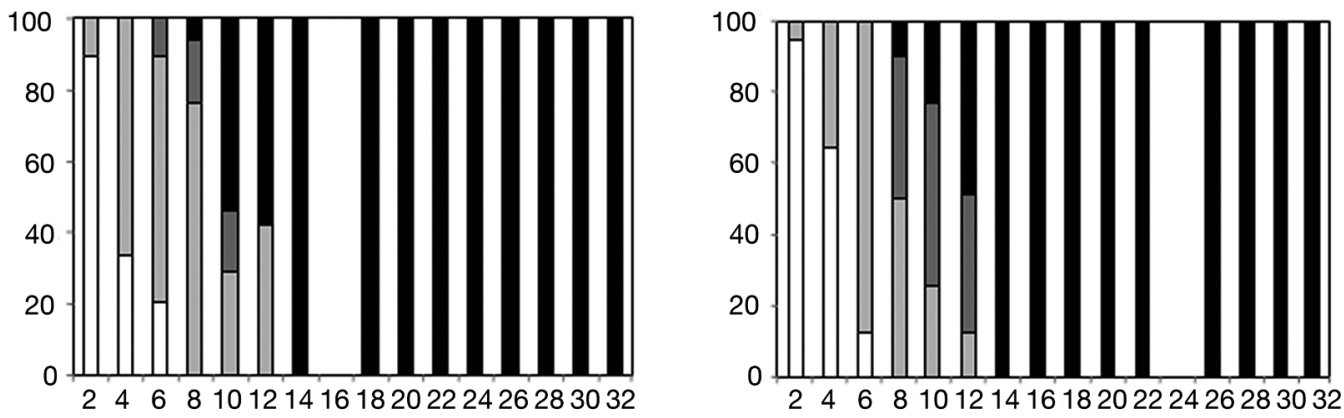

Shell length $(\mathrm{mm})$

Fig. 5. Crepidula coquimbensis. Size-sex distribution for Puerto Aldea and La Herradura I at all 4 sampling times 
tween locations and sampling times. A clear size-sexual dimorphism was observed in both localities (Puerto Aldea: males 7.29 \pm 1.70 [SD] mm, females $22.47 \pm 7.09 \mathrm{~mm}_{\text {; }}$ Student's $t=45.5, \mathrm{p}<0.01$; La Herradura I: males $6.49 \pm 2.16 \mathrm{~mm}$, females $19.91 \pm$ $5.79 \mathrm{~mm}$; Student's $t=31.9, \mathrm{p}<0.01$ ); however, no significant differences were detected in male and female sizes between localities (males Student's $t=$ 1.09, $\mathrm{df}=735, \mathrm{p}>0.05$; females Student's $t=1.33, \mathrm{df}=$ $370, p>0.05$ ). Size-gender distributions evidenced high levels of overlap between the male and female size ranges (Fig. 5). Maximum male size was observed in Puerto Aldea during summer 2011 $(15.2 \mathrm{~mm})$, while the smallest males were observed in the same location during winter 2010 (2.95 mm).

Table 3. Crepidula coquimbensis. Size (mm) at which $50 \%$ of the individuals were male $\left(\mathrm{L}_{50}\right)$ at different localities and time

\begin{tabular}{|lcc|}
\hline & Puerto Aldea & La Herradura I \\
\hline $\mathbf{2 0 1 0}$ & & \\
Summer & 13.01 & 10.49 \\
Winter & 6.99 & 10.47 \\
$\mathbf{2 0 1 1}$ & & \\
Summer & 9.12 & 12.88 \\
Winter & 11.75 & 12.01 \\
\hline
\end{tabular}

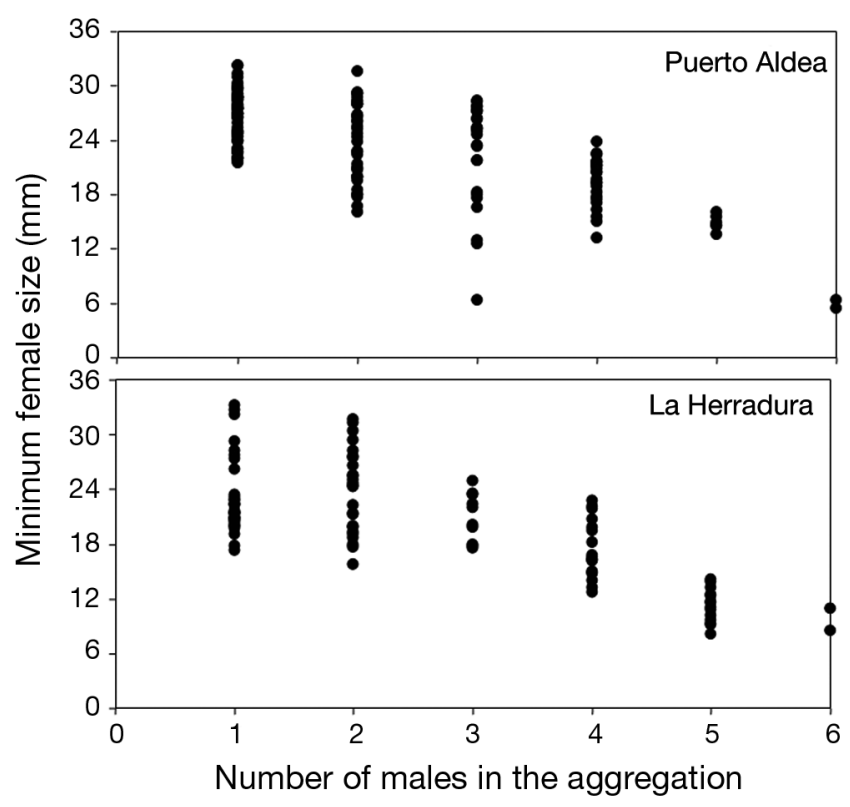

Fig. 6. Crepidula coquimbensis. Relationship between the mean value of the smallest female size in the aggregates observed in each sample unit (quadrat) with the mean number of males per aggregate in the corresponding sample unit in (A) Puerto Aldea and (B) La Herradura I

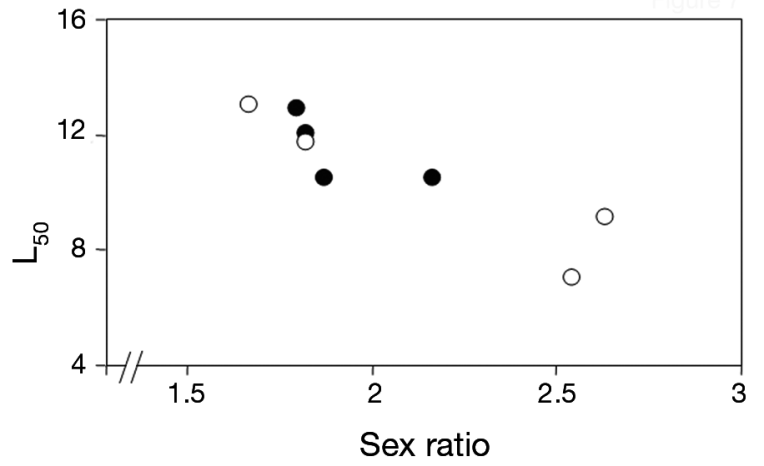

Fig. 7. Crepidula coquimbensis. Relationship between size at which $50 \%$ of the individuals were male $\left(\mathrm{L}_{50}\right)$ and the mean population sex ratio for Puerto Aldea (O) and La Herradura I (

Transitional individuals were found during all sampling periods. Transitional size ranges were variable, with the widest range observed in Puerto Aldea during summer 2010 (Fig. 5). Similarly, minimum female size was highly variable, ranging from 6.96 to $11.68 \mathrm{~mm}$. The size at sex change estimated by logistic regression $\left(\mathrm{L}_{50}\right)$ varied between 6.99 and 13.01 in Puerto Aldea for summer and winter 2010, respectively, with an average value of $10.21 \pm 1.35$ (SE) mm in Puerto Aldea and $11.46 \pm 0.59 \mathrm{~mm}$ in La Herradura I (Table 3).

No clear pattern was observed in the size ranges of different life-cycle stages or in the $\mathrm{L}_{50}$ index through time and space. However, a significant and negative correlation was observed between mean value of the smallest female size in the aggregates observed in each quadrat with the mean number of males per aggregate in the corresponding quadrat (Spearman's rank correlation: Puerto Aldea: $\mathrm{r}_{\mathrm{S}}=-0.63, \mathrm{p}<0.01$; La Herradura I: $\mathrm{r}_{\mathrm{S}}=-0.65, \mathrm{p}<0.01$; Fig. 6) and between mean sex ratio within hosting shells and the $\mathrm{L}_{50}$ value when pooling both populations (Spearman's rank correlation: $r_{S}=-0.93, p<0.05 ;$ Fig. 7).

\section{DISCUSSION}

We have provided evidence that body size at sex change is highly plastic and socially determined in the direct developer and protandric marine gastropod Crepidula coquimbensis. Two populations with restricted genetic flow exhibited highly male-biased sex ratios, but different temporal dynamics of abundance and sex ratio. Morphological traits associated with sex-change strategy, such as minimum female size and $\mathrm{L}_{50}$, varied with time and space. However, 
both traits were highly and negatively correlated with the mean number of males in the aggregation and the mean sex ratio within hosting shells, respectively. Our results suggest that the sex-change strategy of the direct developer C. coquimbensis may be highly variable at spatial and temporal scales, and that the timing of sex change may respond to local conspecific social interactions.

Variability in the population mean abundance of Crepidula coquimbensis observed especially at spatial scales could be explained by local variations in the number of hosting shells occupied by individuals of this species. Population sex ratio was biased toward males and also varied at spatial and time scales. Theoretical models predict male-biased sex ratio in protandric species (Allsop \& West 2004). However, other studies on protandric species of the calyptraeid group have not supported this expectation, and high intra- and inter-specific variability have been observed (e.g. Dupont et al. 2006, Collin et al. 2005, Collin 2006). For example, in a study across 19 Calyptraeidae species, no significant bias in sex ratio was observed in $~ 50 \%$ of species (Collin 2006). According to Collin (2006), this variability and discrepancy between theoretical and empirical data could be explained by the violation of the assumption of the sex allocation theory. This theory assumes a positive relationship between female fecundity and body size and a positive or no relationship between male fecundity and body size (Charnov \& Bull 1989). In $C$. coquimbensis, between 1 and 5 males may inhabit a hosting shell with a female. This aggregation resulted in populations of $C$. coquimbensis with a significant male-biased sex ratio throughout the whole sampling period $(2 \mathrm{yr})$ in the present study. The male bias in this species suggests that the reproductive function of males and females fulfills the assumption of the sex allocation theory. Laboratory measurements have shown that female fecundity of C. coquimbensis increases with body size (A. Brante pers. obs.). In addition, paternity analyses of this species suggest a high potential for sperm storage in the female (up to at least $6 \mathrm{mo}$ ) and a high level of multiple paternity (Brante et al. 2011). Moreover, the same genetic analyses indicated that males of different body sizes in an aggregation may participate in similar proportions as fathers in a brood demonstrating, as the theory predicts, independence between reproductive success and male body size (Brante et al. 2011).

The 3 localities of Crepidula coquimbensis analyzed in the present study had significant genetic differences $\left(F_{\mathrm{ST}}\right)$, suggesting restricted connectivity between them. As a general rule, marine species with limited dispersion have a high degree of population genetic structure (e.g. sea cucumbers: Arndt \& Smith 1998; fishes: Riginos \& Victor 2001, Dawson et al. 2002; barnacles: Sotka et al. 2004; gastropods: Kyle \& Boulding 2000, Collin 2001, Johnson \& Black 2006, Lee \& Boulding 2009; corals: Hellberg 1996, Miller \& Ayre 2008, Pelc et al. 2009; see also a metaanalysis by Kelly \& Palumbi 2010). C. coquimbensis is a direct-developer species and, as with all members of the Calyptraeidae group, females are sedentary and males present low mobility. In addition, according to laboratory experiments, the hermit crab Pagurus edwardsii, which cohabits with C. coquimbensis within a hosting shell, is the only vector promoting the colonization of other shells (A. Brante pers. obs.). All these characteristics could explain the low dispersal potential and population connectivity in C. coquimbensis.

For marine protandric gastropods with low dispersal potential, it has been suggested that sex change will be less responsive to social control and would be less labile (Coe 1938, Hoagland 1978). However, we have shown that the sex-change strategy of Crepidula coquimbensis, a direct-developer species with highly restricted dispersal and moderate gregarious behavior, presented high levels of plasticity and responded to social interactions. C. coquimbensis evidenced a wide overlap between body size range of male and female individuals. This pattern has been described in many protandric gastropods with plastic and socially controlled sex change (e.g. Soong \& Chen 1991, Collin 2000, Chen et al. 2004, Richter \& Luque 2004, Rivera-Ingraham et al. 2011). In addition, minimum female size was negatively correlated with number of males present in the aggregation, and $\mathrm{L}_{50}$ negatively correlated with sex ratio of the aggregation. These results suggest that males of $C$. coquimbensis would accelerate sex change when a higher proportion of males cohabit in a hosting shell. Social control and high plasticity in time to sex change have been reported in 2 other direct-developer calyptraeid species (Warner et al. 1996, Collin et al. 2005). For example, individuals of $C$. norrisiarum changed sex faster in the presence of smaller males than when alone, and no sex change was observed when larger females were present in the aggregation (Warner et al. 1996). Similar results were observed by Collin et al. (2005) in the direct developer C. cf. onyx.

Paternity analyses in Crepidula coquimbensis suggest that male-male competition for access to the female would increase with the number of males in the aggregation (Brante et al. 2011). In addition, 
sperm storage by females may promote sperm competition in the aggregation, which would be more intense as the number of males increases (Brante et al. 2011). In this way, it is possible that a higher number of males in the aggregation reduces male reproductive success and promote sex change at smaller sizes in C. coquimbensis. Paternity analyses carried out in the indirect-developer species $C$. fornicata suggest that multiple paternity and the capacity of females to store sperm promote high competition among males for access to the female as well as high sperm competition, which would ultimately determine the time of sex change in this species (Dupont et al. 2006). More specific experimental protocols and paternity analyses are needed to determine the importance of pre-copulatory (i.e. access to the female) and post-copulatory (i.e. sperm competition) factors determining time of sex change in C. coquimbensis.

In conclusion, field and genetic analyses suggest that in spite of low dispersal potential, high genetic differences between populations, and moderate aggregation behavior of Crepidula coquimbensis, common patterns and mechanisms are modulating time to sex change in this species. Social interactions rather than other life-history characteristics, such as developmental mode, may be driving sex-change strategy in marine protandric gastropods.

Acknowledgements. We thank Ricardo Calderón, Carlos Moraga, and Francisco Ruiz for field assistance on this project. This study was funded by Fondo Nacional de Desarrollo Científico y Tecnológico (FONDECYT) grant \#11090221 to A.B.

\section{LITERATURE CITED}

Allsop DJ, West SA (2003) Changing sex at the same relative body size. Nature 425:783-784

Allsop DJ, West SA (2004) Sex-ratio evolution in sex changing animals. Evolution 58:1019-1027

> Alonzo SH, Warner RR (2000) Allocation to mate guarding or increased sperm production in a Mediterranean wrasse. Am Nat 156:266-275

> Arndt A, Smith MJ (1998) Genetic diversity and population structure in two species of sea cucumber: differing patterns according to mode of development. Mol Ecol 7: 1053-1064

Baeza JA (2006) Testing three models on the adaptive significance of protandric simultaneous hermaphroditism in a marine shrimp. Evolution 60:1840-1850

Baeza JA (2007) Male mating opportunities affect sex allocation in a protrandric-simultaneous hermaphroditic shrimp. Behav Ecol Sociobiol 61:365-370

Bandelt HJ, Forster P, Röhl A (1999) Median-joining networks for inferring intraspecific phylogenies. Mol Biol Evol 16:37-48
Bauer RT (1986) Sex change and life history pattern in the shrimp Thor manningi (Decapoda: Caridea): a novel case of partial protandric hermaphroditism. Biol Bull (Woods Hole) 170:11-31

- Brante A, Fernández M, Viard F (2011) Microsatellite evidence for sperm storage and multiple paternity in the marine gastropod Crepidula coquimbensis. J Exp Mar Biol Ecol 396:83-88

> Brown DI, Olivares CA (1996) A new species of Crepidula (Mollusca: Mesogastropoda: Calyptraeidae) from Chile: additional characters for the identification of eastern Pacific planar Crepidula group. J Nat Hist 30:1443-1458

Charnov EL (1978) Sex ratio: adaptive response to population fluctuations in Pandalid shrimp. Science 200:204-206

$>$ Charnov EL (1979) Natural selection and sex change in Pandalid shrimp: test of a life-history theory. Am Nat 113: 715-734

Charnov EL (1982) The theory of sex allocation. Princeton University Press, Princeton, NJ

$>$ Charnov EL, Bull JJ (1989) Non-Fisherian sex ratios with sex change and environmental sex determination. Nature 338:148-150

Chen MH, Soong K (2003) Sex expression of an immobile coral-inhabiting snail, Quoyula monodonta. Mar Biol 143:351-358

Chen MH, Yang YW, Soong K (1998) Preliminary observations on change of sex by the coral-inhabiting snails Coralliophila violacea. J Exp Mar Biol Ecol 230:207-212

Chen MH, Soong K, Tsai ML (2004) Host effect on size structure and timing of sex change in the coral-inhabiting snail Coralliophila violacea. Mar Biol 144:287-293

> Coe WR (1938) Influence of association on the sexual phases of gastropods having protandric consecutive sexuality. Biol Bull (Woods Hole) 75:274-285

> Collin R (1995) Sex, size, and position: a test of models predicting the size at sex change in the protandrous gastropod Crepidula fornicata. Am Nat 146:815-831

Collin R (2000) Sex change, reproduction and development of Crepidula adunca and Crepidula lingulata (Gastropoda: Calyptraeidae). Veliger 43:24-33

Collin R (2001) The effects of mode of development on phylogeography and population structure of North Atlantic Crepidula (Gastropoda: Calyptraeidae). Mol Ecol 10: 2249-2262

> Collin R (2006) Sex ratio, life history invariants, and patterns of sex change in a family of protandrous gastropods. Evolution 60:735-745

- Collin R, McLellan M, Gruber K, Bailey-Jourdain C (2005) Effects of conspecific associations on size at sex change in three species of calyptraeid gastropods. Mar Ecol Prog Ser 293:89-97

- Dawson MN, Louie KD, Barlow M, Jacobs DK, Swift CC (2002) Comparative phylogeography of sympatric sister species, Clevelandia ios and Eucyclogobius newberryi (Teleostei, Gobiidae), across the California Transition Zone. Mol Ecol 11:1065-1075

Dupont L, Richard J, Paulet YM, Thouzeau G, Viard F (2006) Gregariousness and protandry promote reproductive insurance in the invasive gastropod Crepidula fornicata: evidence from assignment of larval paternity. Mol Ecol 15:3009-3021

- Excoffier L, Smouse PE, Quattro JM (1992) Analysis of molecular variance inferred from metric distances among DNA haplotypes: application to human mitochondrial DNA restriction data. Genetics 131:479-491 
Folmer O, Black M, Hoeh W, Lutz R, Vrijenhoek R (1994) DNA primers for amplification of mitochondrial cytochrome c oxidase subunit I from diverse metazoan invertebrates. Mol Mar Biol Biotechnol 3:294-299

Hall TA (1999) BIOEDIT: a user-friendly biological sequence alignment editor and analysis program for Windows 95/98/NT. Nucleic Acids Symp Ser 41:95-98

Hellberg ME (1996) Dependence of gene flow on geographic distance in two solitary corals with different larval dispersal capabilities. Evolution 50:1167-1175

Hoagland KE (1978) Protandry and the evolution of environmentally-mediated sex change: a study of the Mollusca. Malacologia 17:365-391

> Hoffman SG, Schildhauer MP, Warner RR (1985) The costs of changing sex and the ontogeny of males under contest competition for mates. Evolution 39:915-927

> Johnson MS, Black R (2006) Effects of mode of reproduction on genetic divergence over large spatial and temporal scales in intertidal snails of the genus Bembicium Philippi (Gastropoda: Littorinidae). Biol J Linn Soc 89:689-704

Juchault P (1999) Hermaphroditism and gonochorism. a new hypothesis on the evolution of sexuality in crustacean. C R Acad Sci III 322:423-427

Kelly RP, Palumbi SR (2010) Genetic structure among 50 species of the Northeastern Pacific rocky intertidal community. PLoS ONE 5:e8594

Kyle CJ, Boulding EG (2000) Comparative population genetic structure of marine gastropods (Littorina spp.) with and without pelagic larval dispersal. Mar Biol 137: 835-845

Lee HJ, Boulding EG (2009) Spatial and temporal population genetic structure of four northeastern Pacific littorinid gastropods: the effect of mode of larval development on variation at one mitochondrial and two nuclear DNA markers. Mol Ecol 18:2165-2184

> Lorenzi MC, Sella G, Schleicherová D, Ramella L (2005) Outcrossing hermaphroditic polychaete worms adjust their sex allocation to social conditions. J Evol Biol 18: 1341-1347

Miller KJ, Ayre DJ (2008) Protection of genetic diversity and maintenance of connectivity among reef corals within marine protected areas. Conserv Biol 22:1245-1254

Munday PL, Buston PM, Warner RR (2006) Diversity and flexibility of sex-change strategies in animals. Trends Ecol Evol 21:89-95

Muñoz RC, Warner RR (2003) A new version of the sizeadvantage hypothesis for sex-change: incorporating sperm competition and size-fecundity skew. Am Nat 161: 749-761

Muñoz RC, Warner RR (2004) Testing a new version of the size-advantage hypothesis for sex change: sperm competition and size-skew effects in the bucktooth parrotfish,

Editorial responsibility: Inna Sokolova,

Charlotte, North Carolina, USA
Sparisoma radians. Behav Ecol 15:129-136

> Pelc RA, Warner RR, Gaines SD (2009) Geographical patterns of genetic structure in marine species with contrasting life histories. J Biogeogr 36:1881-1890

> Petersen CW, Warner RR, Shapiro DY, Marconato A (2001) Components of fertilization success in the bluehead wrasse, Thalassoma bifasciatum. Behav Ecol 12:237-245

Polzin T, Daneshmand SV (2003) On Steiner trees and minimum spanning trees in hypergraphs. Oper Res Lett 31: $12-20$

Richter A, Luque A (2004) Sex change of two Mediterranean species of Coralliophilidae. J Mar Biol Assoc UK 84: 383-392

Riginos C, Victor BC (2001) Larval spatial distributions and other early life-history characteristics predict genetic differentiation in eastern Pacific blennioid fishes. Proc R Soc B 268:1931-1936

> Rivera-Ingraham GA, Espinosa F, García-Gómez JC (2011) Environmentally mediated sex change in the endangered limpet Patella ferruginea (Gastropoda: Patellidae). J Molluscan Stud 77:226-231

> Ross RM, Losey GS, Diamond N (1983) Sex change in a coral reef fish: dependence on stimulation and inhibition on relative size. Science 221:574-575

> Rozas J, Rozas R (1995) DnaSP, DNA sequence polymorphism: an interactive program for estimating population genetics parameters from DNA sequence data. Comput Appl Biosci 11:621-625

Sella G (1990) Sex allocation in the simultaneously hermaphroditic polychaete worm Ophryotrocha diadema. Ecology 71:27-32

Soong K, Chen JL (1991) Population structure and sexchange in the coral-inhabiting snail Coralliophila violacea at Hsiao-Liuchiu, Taiwan. Mar Biol 111:81-86

> Sotka EE, Wares JP, Barth JA, Grosberg RK, Palumbi SR (2004) Strong genetic clines and geographical variation in gene flow in the rocky intertidal barnacle Balanus glandula. Mol Ecol 13:2143-2156

Tajima F (1989) Statistical method for testing the neutral mutation hypothesis by DNA polymorphism. Genetics 123:585-595

> Véliz D, Winkler FM, Guisado C (2003) Developmental and genetic evidence for the existence of three morphologically cryptic species of Crepidula in northern Chile. Mar Biol 143:131-142

> Warner RR, Fitch DL, Standish JD (1996) Social control of sex change in the shelf limpet, Crepidula norrisiarum: size specific responses to local group composition. J Exp Mar Biol Ecol 204:155-167

> Wright WG (1989) Intraspecific density mediates sex change in the territorial patellacean limpet Lottia gigantea. Mar Biol 100:353-364

Submitted: September 12, 2011; Accepted: March 29, 2012 Proofs received from author(s): June 22, 2012 